NBER WORKING PAPER SERIES

\title{
DOES EDUCATION REDUCE TEEN FERTILITY? EVIDENCE FROM COMPULSORY SCHOOLING LAWS
}

\author{
Philip DeCicca \\ Harry Krashinsky \\ Working Paper 21594 \\ http://www.nber.org/papers/w21594 \\ NATIONAL BUREAU OF ECONOMIC RESEARCH \\ 1050 Massachusetts Avenue \\ Cambridge, MA 02138 \\ September 2015
}

We thank Maria Fitzpatrick, Mike Grossman, Don Kenkel, Mike Lovenheim, Alan Mathios, Mel Stephens, Tara Watson and seminar participants at Cornell University and NBER for helpful comments. We are especially indebted to Phil Oreopoulos for helpful comments and sharing useful data with us. The views expressed herein are those of the authors and do not necessarily reflect the views of the National Bureau of Economic Research.

NBER working papers are circulated for discussion and comment purposes. They have not been peerreviewed or been subject to the review by the NBER Board of Directors that accompanies official NBER publications.

(C) 2015 by Philip DeCicca and Harry Krashinsky. All rights reserved. Short sections of text, not to exceed two paragraphs, may be quoted without explicit permission provided that full credit, including (C) notice, is given to the source. 
Does Education Reduce Teen Fertility? Evidence from Compulsory Schooling Laws

Philip DeCicca and Harry Krashinsky

NBER Working Paper No. 21594

September 2015

JEL No. I1,I18,I24,J13

\begin{abstract}
$\underline{\text { ABSTRACT }}$
While less-educated women are more likely to give birth as teenagers, there is scant evidence the relationship is causal. We investigate this possibility using variation in compulsory schooling laws (CSLs) to identify the impact of formal education on teen fertility for a large sample of women drawn from multiple waves of the Canadian Census. We find that greater CSL-induced schooling reduces the probability of giving birth as a teenager by roughly two to three percentage points. We find evidence that education affects the timing of births in a way that strongly implies an "incarceration" effect of education. In particular, we find large negative impacts of education on births to young women aged seventeen and eighteen, but little evidence of an effect after these ages, consistent with the idea that being enrolled in school deters fertility in a contemporaneous manner. Our findings are robust to the inclusion of several province-level characteristics including multiple dimensions of school quality, expenditures on public programs and region-specific time trends.
\end{abstract}

\author{
Philip DeCicca \\ Department of Economics \\ 422 Kenneth Taylor Hall \\ McMaster University \\ Hamilton, ON L8S 4M4 \\ CANADA \\ and NBER \\ decicca@mcmaster.ca \\ Harry Krashinsky \\ Harry Krashinsky \\ Centre for Industrial Relations \\ 121 St. George Street \\ University of Toronto \\ Toronto, ON M5S 2E8 \\ Canada \\ harry.krashinsky@utoronto.ca
}




\section{$\underline{1 . \text { Introduction }}$}

Prior research suggests that teen fertility entails significant private and social costs.

Private costs associated with teen childbearing include lower levels of educational attainment by teen mothers as well as diminished labor market outcomes like lower labor force participation and lower wages, while plausibly external costs include greater dependence on welfare programs and an increased need for remedial school services (c.f., Hofferth, 1987; Hoffman et al., 1993; Klepinger et al., 1999; Chevalier and Viitanen, 2003). Beyond maternal costs, children born to teen mothers are more likely to experience reduced life chances due to poor school performance, greater substance abuse and an increased propensity to engage in criminal activity (c.f., Bronars and Grogger, 1994; Grogger, 1997; Francesconi, 2008). While it is not clear that such associations are causal in nature, it seems likely that at least some of the negative consequences associated with teen fertility are indeed causal. To the extent that they are, policies that reduce teen fertility can improve the well-being of women who are predominantly considered disadvantaged relative to the general population.

Despite this possibility, there exists relatively little research on the possible causal effect of schooling on teen childbearing. Indeed, while there is much descriptive evidence that lesseducated women are more likely to give birth as teens, there is considerably less credible evidence that this relationship is causal in nature. We investigate the causal relationship between educational attainment and teen childbearing for a large sample of women drawn from multiple waves of the Canadian Census. More precisely, we exploit variation in compulsory schooling laws (CSLs) in an instrumental variables framework to identify the impact of schooling on fertility as a teenager. While prior studies have been hampered by weak instruments, our estimates are unique in the literature because they imply a strong first stage relationship. In turn, 
we find that CSL-induced schooling reduces the probability of giving birth as a teenager by between two to three percentage points, which is proportionally substantial. We also explore possible mechanisms underlying this relationship by examining the timing of our estimates as it relates to age of first birth. We find evidence that education affects the timing of births in a way that suggests a strong "incarceration" effect. In particular, we find large negative impacts of education on births to young women aged seventeen and eighteen, but little evidence of an effect after these ages, consistent with the idea that being enrolled in school deters fertility in a contemporaneous manner. We also examine teen fertility on the intensive margin and find estimates consistent with this interpretation.

To address a recent critique of the broader CSL literature by Stephens and Yang (2014), we also include controls for school quality in our models, in addition to other province-level characteristics. Our main estimates are quite robust to their inclusion. To the extent that avoiding a teen birth leads to improved life outcomes, our findings suggest that policies which attempt to increase educational attainment at the lower end of the distribution may have substantial non-pecuniary returns, at least in this dimension.

In the following section, we provide background information on Canadian compulsory school laws, discuss mechanisms by which schooling may affect teen fertility decisions and review related literature. Section 3 describes our data, focusing on key definitions such as how we label teen mothers, and also the relevant history of minimum school leaving ages which provide the variation which we use to identify the impact of schooling on teen fertility. Section 4 presents our empirical strategy which relies on instrumental variables estimation. We also discuss issues surrounding appropriate variance estimation when there are few clusters or sources of independent variation. Since CSLs are a matter of provincial policy and since there are only 
ten Canadian provinces, we implement the Wild cluster bootstrap procedure outlined in Cameron and Miller (2015). Section 5 presents our findings, while Section 6 discusses them and concludes the paper.

\section{Background}

\subsection{A Brief History of Canadian CSLs}

Despite relatively recent attention by economists, compulsory schooling laws have existed in North America for well over a century. Perhaps not surprisingly, their pattern of development in Canada and the United States is quite similar, mirroring other key similarities including education being a function of state/provincial governments delivered by local governments and the use of similar, most often local, funding mechanisms in the relevant time periods (Katz, 1976). In what follows, we briefly describe the history of CSLs in Canada drawing heavily on existing research (Phillips, 1957; Axelrod, 1997; Oreopoulos, 2005). We describe the law changes we use for identification purposes in greater detail in the following section.

As in the United States, compulsory schooling laws in Canada were first enacted in the latter part of the $19^{\text {th }}$ Century (Katz, 1976). Early versions of these laws were subject to many exemptions, most often based on the age of children, their necessity in supporting their families and distance lived from school. Generally speaking, however, these laws became more binding over time. Though an early adopter, the province of Ontario provides a good example of the typical evolution of CSLs in Canada. In 1871, Ontario became the first province in Canada to enact a compulsory schooling law, requiring children aged seven to twelve to attend school for at least four months per year. ${ }^{1}$ Two decades later these ages were raised to between eight and

\footnotetext{
${ }^{1}$ CSLs appeared in British Columbia shortly afterward in 1873 with most Canadian provinces enacting them by the end of the first decade of $20^{\text {th }}$ Century. Quebec is an interesting exception. Despite high levels of school
} 
fourteen, and legislation introduced penalties for non-compliance as well as for hiring school aged children, though many exemptions remained. For example, children under ten were exempted if they lived more than 2 miles from school while children ten and over were similarly exempted if they lived more than 3 miles away. Moreover, there was lax enforcement of the law, particularly in rural areas. ${ }^{2}$ By the mid-1950s, the Schools Administration Act raised the age of school attendance to sixteen for all students in Ontario, though farm children over the age of fourteen were exempted as were children who were deemed to be essential to their family's subsistence. Similar to other Canadian provinces, even these exemptions were lifted in the early 1970s, which is also consistent with many U.S. states (Katz, 1976). Moreover, some Canadian provinces have further increased the age of compulsory attendance. For example, New Brunswick raised it to eighteen in 2000, as did Ontario in 2007 and Manitoba in 2011. Again, note that this broad overview does not explicitly discuss the law changes we use in our analysis; instead we do this in Section 3.

\subsection{Why might compulsory schooling affect teen fertility?}

Prior work outlines two broad mechanisms by which compulsory education might affect fertility. The first, consistent with economic models based on human capital theory, suggests that education lowers female fertility through an increase in the opportunity cost of time. ${ }^{3}$ In short, if there are positive returns to additional schooling, women's labor market opportunities,

attendance, Quebec did not enact formal CSL legislation until 1943, though it had relatively strict child labor laws which restricted children from working until age sixteen unless they could read and write.

${ }^{2}$ The deference shown to rural areas, mostly based on their agrarian nature and extensive use of child labor, is also apparent in the Adolescent School Attendance Act of 1921 whereby Ontario increased the compulsory age of attendance from fourteen to sixteen years old, but only for young adults living in urban areas. Perhaps not surprisingly, newly required fourteen and fifteen year olds were exempted from the law if they were employed at home or for wages and if they possessed a parent-endorsed "certificate of employment", which exempted youth from minimum school leaving laws, were often obtained by passing equivalency tests, typically at the level of grade 7 or 8 , but sometimes merely tested basic skills like reading or writing. Interestingly, these young adults were still required to attend part-time instruction in the evenings, where such classes existed.

${ }^{3}$ Following Black, Devereux and Salvanes (2008), we collectively label these explanations "human capital" mechanisms in the discussion that follows. 
including their wage rates, improve. Since children are highly time-intensive, such increases might alter female fertility decisions, with the primary prediction that they reduce total fertility. ${ }^{4}$ Indeed, theoretical models that consider lifecycle fertility highlight the wage rate as a key parameter (Willis, 1973; Wolpin, 1984; Barro and Becker, 1988; Hotz and Miller, 1988). While the literature understandably focuses on lifetime fertility, it is conceivable that teen fertility is also altered. If, for instance, additional compulsory schooling sufficiently improves the labor market opportunities of high school aged girls and if those impacted recognize this, it might change their near-term behavior. In other words, even if the bulk of returns to additional education are realized beyond the teen years, they may affect teen fertility if girls are even somewhat forward-looking and did not previously realize the economic opportunities afforded by additional education. In addition, it is possible that additional education improves either the amount of health information possessed or the efficiency with which individuals use it (Grossman, 1972; Rosenzweig and Schultz, 1982; Kenkel, 1991). For example, if education improves information regarding alternative forms of birth control and/or their appropriate use, fertility might be impacted. Indeed, prior work has shown that women with greater levels of formal education are more likely to use birth control and to use it appropriately (c.f., Balakrishnan et al., 1985; Tanfer and Horn, 1985). Again, while it seems likely that these human capital related mechanisms affect longer-run fertility, it is possible that they affect nearer-term, and hence teen, fertility.

The second broad mechanism by which education might affect fertility is more mechanical in nature and involves the allocation of time. In particular, when individuals are in school there is less time to engage in behaviors that occur outside of school, including sexual

\footnotetext{
${ }^{4}$ This explanation only references the substitution effect; there may be income effects which, if children are normal goods, the corresponding increase in income would increase investment in children; however, the dominant thinking is that such income effects are small relative to substitution effects.
} 
activity. ${ }^{5}$ Naturally, this implies that minimum school leaving ages have their desired effect; that is, they are indeed binding on the amount of formal schooling one receives which implies greater time devoted to schooling. More generally, they must also bind on a non-trivial fraction of students. In principle, greater seat time in school may lead to reduced fertility as might programs or services offered in the school setting. Lovenheim et al. (2014), for instance, find that schoolbased family health centers reduce teen fertility. While their estimates are specific to the U.S. and cover a different time period than ours, they highlight a possible school-based mechanism. Peer effects are another possible avenue through which incarceration may deter fertility. For example, individuals induced by CSLs to remain in school (i.e., compliers) may spend less time outside of school with peers who continue to drop out (i.e., non-compliers) than prior to the CSL. In turn, this could mean less time with peers who might engage in risky behaviors that might influence sexual behavior and hence teen fertility.

Conceptually, these two broad mechanisms have different implications regarding the timing of fertility. In particular, if the incarceration effect operates to the exclusion of the human capital effect, as we describe it, one would expect less fertility around the relevant compulsory schooling ages. More precisely, one would expect to observe effects only in that relatively narrow period and not beyond it. Nevertheless, as noted above, the human capital mechanisms described might also affect near-term fertility if girls induced to complete additional education contemporaneously realize the potential returns to their now higher education level. Therefore, finding only a near-term effect of education on fertility, while most ostensibly consistent with incarceration, could also be due to what we label human capital mechanisms. Of course, it is plausible that higher minimum school leaving age laws have both incarceration and human capital effects; in other words, it is entirely possible for additional mandated schooling to impact

\footnotetext{
${ }^{5}$ In what follows, we label this mechanism an "incarceration effect" as in Black, Devereux and Salvanes (2008).
} 
fertility in the short and longer runs for different reasons. Though imperfect, we explore each of these broad mechanisms by examining the impact of formal schooling on fertility at various maternal ages extending from age 16 to 22 . Our findings point to a pure incarceration effect since education reduces fertility in the late teen years, but not into early adulthood.

\subsection{Existing studies on education and teen fertility}

The relationship between education and labor market outcomes like earnings and employment has long interested economists. More recently, economists have become interested in broader notions of returns to education, including its possible impact on non-pecuniary outcomes like health, crime, and civic-oriented behavior. It is well-recognized that estimating the causal effect of education on any of these outcomes is challenging because educational choices reflect factors other than schooling, factors often not easily observed by the researcher. As a result, and in the absence of random assignment to different levels of education, economists have increasingly explored quasi-random variation in schooling induced by natural events or government policy. In what follows, we first briefly describe the broader literature and then focus on two studies which are most relevant to our work. We also review a recent study which challenges much of the broader literature and describe how we deal with issues raised therein.

One government policy which has received much attention is compulsory schooling laws (CSLs). Several studies use different parameterizations of these laws to instrument for educational attainment or estimate reduced form relationships. The earliest of these studies focused on the amount of schooling required, in essence subtracting compulsory school starting ages from corresponding school leaving ages, and studied educational attainment as well as labor market outcomes such as wage rates and earnings (c.f., Lang and Kropp, 1986; Acemoglu and Angrist, 2000, Goldin and Katz, 2003, Black, Devereux and Salvanes, 2005; Oreopoulous, 
2006). Later studies focused on broader outcomes and tended to find positive social impacts of increased formal schooling (c.f., Lleras-Muney, 2002, Lochner and Moretti, 2004, LlerasMuney, 2005). ${ }^{6}$ The findings of even more recent, and in large part, non-U.S. based studies, are decidedly more mixed both with respect to labor market outcomes (c.f., Meghir and Palme, 2005; Pischke and von Wachter, 2008; Grenet, 2013) and also broader social outcomes (c.f., Clark and Royer, 2013).

Two studies are of greatest relevance to our work, with the second being most relevant. First, McCrary and Royer (2011) examine the relationship between maternal education and fertility, as part of a larger study focusing on child health. Using data from California and Texas, these authors implement a regression discontinuity strategy based on school starting ages. They find little evidence of a relationship between increases in CSL-induced education and fertility. ${ }^{7}$ While their data are very appropriate for examining the relationship between maternal education and child health, they are more limited in examining fertility since they use natality data which, by its nature, is comprised solely of births (i.e., those females who have given birth). The second paper, Black, Devereux and Salvanes (2008) is more directly relevant to our work. These authors examine the impact of educational attainment on teen fertility using compulsory schooling reforms in the United States and Norway. Of the two corresponding sets of analysis, the U.S. component is most similar to our work since it focuses on minimum school-leaving ages as well as the similarity of U.S. and Canadian educational systems. In particular, Black, Devereux and Salvanes (2008) use U.S. Census data from 1940 to 1980 and include women ages 20 to 30 in a given census year. As in our analysis, they infer whether a woman's first birth

\footnotetext{
${ }^{6}$ For an excellent review of work related to the social or non-pecuniary benefits of compulsory law-induced schooling see Oreopoulos and Salvanes (2011).

${ }^{7}$ McCrary and Royer (2011) also find no relationship between such education and child health, which again is the focus of their study.
} 
occurred in her teen years from her current household composition; in particular, the age difference between the mother and her eldest co-resident child. Unlike most other literature, the authors do not use these laws to instrument educational attainment since they do not find a systematic first-stage relationship. ${ }^{8}$ Instead, they estimate reduced form models that include state and cohort fixed effects as well as models that include state trends and variables that proxy labor market conditions. Their main estimates imply that an extra year of schooling is associated with between a five and nine percent decrease in teen fertility, depending on whether the CSL in question requires school attendance until age 16 or age 17, respectively. Finally, Black, Devereux and Salvanes (2008) test the notion of whether "incarceration" versus "human capital" mechanisms drive their estimates and find evidence for both explanations, though relatively weaker evidence for incarceration. We discuss these issues in greater detail later in the paper. Despite reasonably consistent findings of a positive relationship between compulsory schooling laws and outcomes like earnings, health, civic behavior and others, Stephens and Yang (2014) pose what may be a serious challenge to this literature. In particular, these authors revisit many of the CSL-induced education findings cited earlier, but systematically discover that they are not robust to the inclusion of a region-specific trend variable; the implication being that there exist factors other than CSLs which have changed over the period in question and that these factors may have impacted the outcomes studied. More precisely, Stephens and Yang (2014) find that inclusion of a region-specific trend variable does not greatly affect the relevant first stage estimates (i.e., the regression of educational attainment on CSLs), but substantially alters corresponding structural estimates (i.e., the estimate of instrumented education on the ultimate

\footnotetext{
${ }^{8}$ Black, Devereux and Salvanes (2008) note that the lack of statistical significance is due to earlier studies clustering on state-year cells, rather than just state cells. More recent work suggests that clustering at the state level is preferred. That said, there is concern when the number of clusters is "too small". Since there are only ten Canadian provinces, we cluster at the province level and also implement the Wild cluster bootstrap procedure outlined in Cameron and Miller (2015) as discussed in detail in Section 4.
} 
outcome). These authors also explore one possible factor that changed along with CSLs, namely "school quality" as measured by Card and Krueger (1992). ${ }^{9}$ When included, they find similar impacts on the estimates of studies they replicate; I.e., first stage estimates that remain relatively strong, but substantially different structural estimates. While this does not necessarily imply that school quality is "the" missing factor, the overall pattern of their findings casts at least some doubt on the findings of earlier work since they suggest pathways other than CSL-induced increases in formal schooling.

We address this critique in two ways - one conceptual and one empirical. First, we note that our main finding, as previewed in the introduction, is strongly consistent with an incarceration effect, rather than a human capital effect. In essence, our finding reflects the mechanical nature of schooling's impact on time use. As such, it is plausibly independent of factors like school quality to the extent that quality does not influence the efficacy of CSLs in increasing schooling. That said, we include a measure similar to the Card and Krueger (1992) measures of school quality used by Stephens and Yang (2014), but specific to Canadian provinces in our models, as well as other provincial-level controls such as aggregate program spending. As will be seen, our estimates — both first stage and structural — are robust to their inclusion. While we realize that this does not rule out all other factors, we believe that it rules out a potentially important one.

\section{Data}

The data used in this study are assembled from the 1976, 1981, 1986, and 1991 confidential extracts of the Canadian Census. ${ }^{10}$ The sample is comprised of women between the

\footnotetext{
${ }^{9}$ These school quality measures, which vary by state and year, include pupil to teacher ratio, length of the school year, and relative teacher salaries.

${ }^{10}$ The confidential extracts of the Census were essential for this exercise because of a number of factors. Only the confidential Census extracts contain an individual's exact date of birth, as well as the necessary identifiers to link
} 
ages of 22 and 35, and for these women, it was determined whether or not they had given birth to a child by a certain age. This could not be ascertained from a direct survey question posed to the women in the Census, since the Census does not directly ask women about the age at which they first gave birth. But since the Census is a household-level survey, it contains variables that identify individual households as well as the families within those households. Specifically, it identifies "Census Families"11 living within these households (since some households contain multiple families), as well as characteristics of family members. These questions could be exploited to determine the age at which women in the sample had their first child. This was accomplished by calculating the age differential between the female head of the household (or female partner of the head of the household) and their eldest offspring present in the household. The analysis will use this age gap to consider women who did or did not give birth to children by a particular age (in particular, during their teenaged years). For the sake of reference, Figure 1 displays a schematic for the method used to identify potential mothers in our sample.

Given the method used to identify the age at which women in our sample give birth, it is important to note the maximal age of the female household head is an important consideration for the analysis. As the female household head becomes progressively older, it is possible that their eldest child is no longer present in the household. In the Census, virtually all heads of household are at least 17 or 18 years old; thus, by setting the maximum age of women in the sample to thirty-five years of age we can assure that this misclassification bias is effectively eliminated.

parents and children. The confidential version of the 1971 Census is also available in Statistics Canada Research Data Centres, but uses a different classification system to identify Census families. For consistency's sake, we have not used that Census extract.

${ }^{11}$ A "Census family" refers to a married couple and the children, if any, of either or both spouses; a couple living common law and the children, if any, of either or both partners; or, a lone parent of any marital status with at least one child living in the same dwelling and that child or those children. 
To provide a general sense of the characteristics of the sample, Table 1 displays means and standard deviations of certain variables for women in each of the four Censuses who either did or did not give birth to their eldest child as a teenager. The variables in the samples are: age (in years), educational attainment (in years), annual earnings (in the year prior to the Census, and reported in terms of real 2002 dollars), the number of weeks worked in the year prior to the Census, and the proportion who are married. The tables compare women between the ages of 22 and 35 , and the relative differences in the characteristics demonstrate that women who have had children in their teens are significantly less-educated, work fewer weeks of the year, and earn less money ${ }^{12}$ than women who have not had children in their teens. Although this finding has been documented elsewhere in the literature, it confirms that women who have had children as teenagers also exhibit worse economic outcomes than those who have not had children as teens.

\section{Regression Results}

Although not conclusive, the evidence in Table 1 suggests that lower educational attainment may be a key factor in determining teen fertility. To further investigate the relationship between these two variables, we first estimate the following OLS regression:

(Proportion of Women who gave birth by age A) bpc

$$
=\beta(\text { Years of Education })_{b p c}+\gamma X_{b p c}+\alpha_{p}+\eta_{c}+\delta_{t}+e_{b p c}
$$

In this regression, all of the variables contain individual data points from data consisting of means calculated for birth cohort $b$, in each province $p$, and each Census extract $c$. As seen in Table 2, the dependent variable changes according to the age by which women have given birth (denoted above as "A"), from 16 to 22 years old. The other control variables in the regression $\left(X_{b p c}\right)$ include: age as well as its square, cube and quartic; controls for rural status, the percent

\footnotetext{
${ }^{12}$ The 1976 Census did not contain information on earnings or weeks worked, so the mean of this variable was determined from the other three Censuses.
} 
employed in manufacturing, married status, aboriginal status, and immigrant status; and fixed effects for province of birth, year of birth and the census extract. Furthermore, we seek to ensure that our estimates are not prone to the issues identified in recent work by Stephens and Yang (2014) who found that the IV return to education was not significantly different from zero when controls such as school quality specific to the U.S. state and year were included in the IV framework. To address this, we include three variables to account for school quality within each province and birth cohort: the annual per-capita spending by the provincial government on education, the annual per-capita number of schools in the province, and the annual per-capita number of teachers in the province. In a separate model, we include region-level trends, again designed to address the critique of Stephens and Yang (2014). Finally, since we are concerned about potential within-province correlation of the errors, we calculate standard errors using a Wild cluster bootstrap procedure - since Canada has only ten provinces, Cameron et al. (2008, 2015) suggest this is the appropriate clustering approach.

The second row of Table 2 presents OLS estimates of the impact of years of education on the proportion of women who gave birth by a given age, as described above. For brevity, we present only the coefficient on years of education along with p-values that were calculated using the Wild cluster bootstrap procedure. The estimates in the second row of Table 2 are inconclusive. While the first three, corresponding to ages 16,17 and 18 , are negative, the remaining coefficients in this row are positive. Moreover, all estimates in the second row of Table 2 are statistically insignificant at conventional levels. Overall, there is no clear relationship between education and the proportion of mothers who gave birth at a young age.

However, these regressions are descriptive in nature, and do not have a causal interpretation, given the clear endogeneity of the education variable. Instead, it is necessary to 
find an approach that will purge the model of its endogeneity. We employ a two-stage least squares approach that relies upon compulsory schooling laws as an instrument for educational attainment. To begin, we estimate the first stage of the model:

$$
E D U C_{b p c}=\lambda C S L_{b p}+\rho X_{b p c}+\theta_{p}+\mu_{b}+\psi_{c}+v_{b p c}
$$

Once again, $\mathrm{p}$ represents province, $\mathrm{b}$ represents cohort of birth and $\mathrm{c}$ represents Census year. $\mathbf{E D U C}_{\mathrm{bpc}}$ represents the average years of education of women from a particular province, $\mathrm{p}$, born in a particular birth cohort, b, in a particular Census year, c. CSL $\mathbf{C L}_{\mathrm{pp}}$ represents our compulsory schooling law instrument which is based on province-determined minimum school leaving ages and is specific to particular birth cohorts, $\mathbf{X}_{\mathrm{bpc}}$ represents provincial level controls mentioned above including the three province level school quality variables mentioned and $\boldsymbol{\theta}_{\mathrm{p}}, \boldsymbol{\mu}_{\mathrm{b}}$ and $\boldsymbol{\psi}_{\mathrm{c}}$ represent province, birth cohort and Census year fixed effects, respectively, while $\mathbf{v}_{\mathrm{bpc}}$ is the error term. Since this specification includes province and time related fixed effects, the coefficients on the CSL variables $(\lambda)$ are identified by both variation in CSLs across provinces as well as variation within-province over time. We specify the CSL instrument as a dummy variable equal to one if the birth cohort may only drop out of the province's educational system once they are either 15 or 16 years of age, and zero otherwise. ${ }^{13}$ Again, due to the relatively small number of clusters in our data, the Wild bootstrap clustering procedure was necessary for the two-stage least-squares estimation approach, and this has been discussed by Davidson and MacKinnon (2010).

The fourth row of Table 2 reports the main finding from the first stage, which is that the instrument induces a higher level of educational attainment, and has an acceptably small p-value. This suggests that our sample does not suffer from a weak instrument problem within this

\footnotetext{
${ }^{13}$ Information on the specific timing for changes in these laws is presented in Appendix Table 1.
} 
framework. $^{14}$ This is a substantive improvement over the existing literature, which was unable to find a workable first stage with American and Norwegian data. Furthermore, our estimates are similar to other papers that have used the Canadian Census to explore the relationship between compulsory schooling laws and educational attainment. ${ }^{15}$ We investigate our first stage estimates in more detail shortly.

Our second stage results are presented in the third row of Table 2, and differ substantially from the corresponding OLS estimates directly above them. Looking across the third row, education has no significant effect on having had a child by the age of 16 , but there is a negative and statistically significant effect of having a child by age 17 or 18 . In particular, our estimates imply that an additional year of education reduces the fraction of teen births at these ages by roughly two and three percentage points respectively, which translate proportionally to one-third and one-half relative to the dependent mean. Beyond this point - having a child by 19 or later the negative impact of education disappears, as the remaining coefficients in this row are statistically indistinguishable from zero. Appendix Table 2 mirrors Table 2, but includes regionspecific trends to further address the Stephens and Yang (2014) critique. Again, we find evidence of a strong first stage relationship between our compulsory schooling law instrument and years of formal education. More to the point, we find that CSL-induced education reduces fertility only at ages 17 and 18, as before, which is consistent with an incarceration effect of education on fertility. While the implied magnitudes are somewhat smaller than in Table 2, the pattern is very similar.

The consistent pattern of estimates presented in Table 2 and Appendix Table 2 suggests that education does not have a permanent, causal impact on the fertility patterns of young

\footnotetext{
${ }^{14}$ As before, the standard errors and related p-values for the first stage were determined using a Wild bootstrap clustering procedure.

${ }^{15}$ Specifically, our estimates are similar to those presented by Oreopoulos $(2007,2008)$.
} 
women. Although raising the drop-out age does effectively compel students to obtain more education, a significant causal impact of this change is only evident one or two years after the students are permitted to leave school. We interpret these results as being supportive of an incarceration effect of education. If young women were postponing their fertility in order to maximize the return to their increased education, then the IV results would be significantly negative well after they had exited school. Instead, the results suggest that there is - at best two years during which fertility is lower for compliers, and then this effect expires. This is consistent with an incarceration effect where compliers are constrained in having children while in school, but are seeking to have children almost as soon as they are able to leave school. In the case where the law permits a woman to leave school at the age of 14 , given the time necessary to find a mate as well as a gestation period of 9 months, women intent on having children relatively soon after they leave school would report doing so by the age of 16 or 17 . By comparison, compliers who are also seeking to begin a family as quickly as possible once they leave school at the age of 16 would be less likely to have children by the age of 17 or 18 , but equally likely to have had a child by the age of 19 or 20 . This is precisely what the two-stage least squares results show us.

To further consider the incarceration effect implied by Table 2, Table 3 presents more detail on the impact of our instrumental variable - whether a province requires a student to remain in school until 15 or 16 years of age - on various levels of educational attainment. Specifically, the table seeks to determine the effect on the probability of completing a particular grade level; this is accomplished by running the following regression:

$$
\text { Percent Who Completed Grade } G_{b p c}=\lambda C S L_{b p}+\rho X_{b p c}+\theta_{p}+\mu_{b}+\psi_{c}+v_{b p c}
$$


Once again, $\mathrm{p}$ represents province, $\mathrm{b}$ represents cohort of birth and $\mathrm{c}$ represents Census year. (Percent Who Completed Grade G) $)_{\text {bpc }}$ represents the proportion of women from a particular province, $\mathrm{p}$, born in a particular birth cohort, $\mathrm{b}$, in a particular Census year, $\mathrm{c}$, who completed a particular grade level, denoted by "G". In the table, "G" ranges from grade 7 to at least one year of college. CSL $_{\mathrm{bp}}$ represents our compulsory schooling law instrument which is based on province-determined minimum school leaving ages and is specific to particular birth cohorts, $\mathbf{X}_{\mathrm{bpc}}$ represents provincial level controls mentioned above including the three province level school quality variables mentioned and $\boldsymbol{\theta}_{\mathrm{p}}, \boldsymbol{\mu}_{\mathrm{b}}$ and $\boldsymbol{\psi}_{\mathrm{c}}$ represent province, birth cohort and Census year fixed effects, respectively, while $\mathbf{v}_{\mathrm{bpc}}$ is the error term.

As seen in Table 3, the instrument increases educational attainment where it is expected to do so, if indeed it is operative - that is, a higher dropout age has a heterogeneous impact on the probability of completing different levels of education. The first four columns of the table demonstrate that the instrument has a positive effect on the probability of completing grades 7 through 10. The first row of the table shows that over ninety percent of the women in our sample completed these grades. The instrument has a statistically significant effect whose magnitude is large: our increase in drop-out ages is associated with a roughly six- to seven-percentage point increase in the probability of completing these grades. The fifth column of the table shows that there is also a significant impact on the probability of completing the eleventh grade. Roughly 83 percent of the women in our sample completed this grade, and our instrument is associated with a five-percentage-point increase in the likelihood of completing this grade.

The results in the first five columns of Table 3 suggest that the increase in the drop-out age did increase educational attainment in these particular grades. And this result is not unexpected: since students are at least sixteen years old once they have completed grade eleven, 
the results suggest that the instrument has had an effect on grade completion up to the point where it is legally binding. However, once the instrument is no longer legally binding, its effect is negligible. The last two columns show that the instrument did not have a statistically significant effect on the completion of high school, and actually had a negative effect on the completion of a year of post-secondary education.

Taken in conjunction with the results from Table 2, the findings in Table 3 suggest that the fertility patterns of young women match well with the grade completion patterns of young women. As the legally-mandated drop-out age increased, this significantly increased the grade completion rates up to grade eleven (the last grade where these laws are generally binding). Once these laws were no longer binding, their effect on educational attainment was diminished. And once the effect of the law was diminished, the results in Table 2 suggest that the propensity to conceive a first child increased right away. Once a female student leaves grade eleven, she is at least seventeen years old. If she were to seek to conceive a child as soon as she left school (but refrain from conceiving while she was attending school), then we would expect to see the results that are evident in Table 2. Compared to a woman who was permitted leave school at fourteen, a woman required to attend school until she was sixteen should exhibit a lower propensity to have a child by seventeen or eighteen (given the nine-month gestation period for a child), but an equal likelihood of conceiving a child by the age of nineteen. All of our various IV specifications confirm this result.

Finally, we present estimates of the impact of education on the total number of children conceived by various young ages in Table 4 and Appendix Table 3. The evidence in Table 2 demonstrated that additional education induced by changes in compulsory schooling laws temporarily delayed the first child conceived by a young woman, but Table 2 does not address 
fertility patterns beyond the first child. That is, Table 2 and Appendix Table 2 report evidence on the extensive margin for fertility, but Table 4 and Appendix Table 3 report evidence on the intensive margin for fertility. The models estimated are identical in method and specification to those presented in Table 2, but now the dependent variable is the number of children, rather than whether a woman has any children by various given ages. In both tables, we find evidence that CSL-induced education reduces the number of children, but only at ages 17 and 18, which is consistent with our earlier models and again consistent with an "incarceration" effect of schooling on teen fertility.

\section{Conclusion}

The childbearing tendencies of young women have long been a matter of policy concern, and although the literature has explored different factors that might impact this outcome, there has not yet been a documentation of the causal effect of education on the fertility of young women. Broadly, there are two theories which have different predictions for the way in which education could impact childbearing for young women. First, "time-use" theories emphasize the "incarceration effect" of education, and suggest that spending more time in school leaves less time for other activities, and hence decreases the likelihood of childbearing. As emphasized in

this paper, this theory has strong predictions about the timing of fertility decisions as compulsory schooling laws change: when more schooling is required, fertility decisions are temporarily postponed, but not permanently decreased. Second, "human capital" theories argue that increased productivity gained through additional schooling makes it more expensive to leave the labor market to bear and raise a child. This substitution effect would have a longer-term impact for decreasing fertility rates. 
The results in this paper demonstrate that there is strong evidence increased educational attainment causes fertility to decline around the margin where students may first leave school, but not in a nearby neighbourhood of ages. Furthermore, these effects are robust to different specifications of our model, which is critical, given the recent critique of Stephens and Yang (2014) on the compulsory schooling law literature. Overall, we argue that the transitory negative effect of education is consistent with an incarceration effect, but is more difficult to reconcile with theories which argue in favour of human capital effects influencing the fertility patterns of young women. Given our results, we can only detect a causal, negative impact of education on fertility for women giving birth at the age of 17 or 18 , which is consistent with compliers in our data seeking to bear children almost as soon as they are permitted to leave school.

That said, the magnitude of our findings at these ages represent substantial reductions in teen fertility. Our main estimates imply that an extra year of schooling leads to a two and three percentage point reduction in fertility at age 17 and 18 respectively, which are large proportionally since mean fertility is low at these ages. To the extent that they reflect causality, our findings imply that policies which seek to increase educational attainment in the lower tail of the education distribution may reduce teen fertility. In turn, if reduced teen childbearing results in better life outcomes, our findings point to a role for educational policy in improving the life chances of lower socioeconomic status women. 


\section{References}

Acemogu, Daron and Joshua Angrist (2000). "How large are human capital externalities?

Evidence from compulsory schooling laws", NBER Macroeconomics Annual, Volume 15: 9-74.

Axelrod, Paul (1997). The promise of schooling: Education in Canada, 1800-1914. Toronto, Ontario: University of Toronto Press.

Balakrishnan, T.R., Krotki, K. and Lapierre-Adamcyk, E. (1985). "Contraceptive use in Canada, 1984”, Family Planning Perspectives, 17(5): 209-215.

Barro, Robert and Gary S. Becker (1988). "A reformulation of the economic theory of fertility", Quarterly Journal of Economics, 103(1): 1-25.

Black, Sandra E., Paul J. Devereux and Kjell G. Salvanes (2005). "Why the apples doesn't fall far: Understanding intergenerational transmission of human capital", American Economic Review, 95(1): 437-449.

Black, Sandra E., Paul J. Devereux and Kjell G. Salvanes (2008). "Staying in the classroom and out of the maternity ward: The effect of compulsory schooling laws on teenage births", Economic Journal, 118(July): 1025-1054.

Bronars, Stephen G. and Jeff Grogger (1994). "The economic consequences of unwed motherhood: using twin births as a natural experiment, American Economic Review, 84: 11411156.

Cameron, A. Colin, Jonah Gelbach and Douglas Miller (2008). "Bootstrap based improvements for inference with clustered errors, Review of Economics and Statistics, 90: 414-427.

Cameron, A. Colin and Douglas Miller (2015). "A practitioner's guide to cluster-robust inference, Journal of Human Resources, 50(2): 317-373.

Card, David and Alan B. Krueger (1992). "Does school quality matter? Returns to education and the characteristics of public schools in the United States", Journal of Political Economy, 100(1): $1-40$.

Chevalier, Arnaud and Tarja Viitanen (2003). "The long-run labor market consequences of teenage motherhood in Britain, Journal of Population Economics, 16: 323-343.

Clark, Damon and Heather Royer (2013). "The effect of education on adult mortality and health", American Economic Review, 103(6): 2087-2120.

Davidson, Russell and James G. MacKinnon (2010). "Wild bootstrap tests for IV estimation", Journal of Business and Economic Statistics, 28:128-144.

Francesconi, Marco (2008). "Adult outcomes for children of teenage mothers", Scandanavian Journal of Economics, 110(1): 93-117. 
Goldin, Claudia and Lawrence Katz (2003). "Mass secondary schooling and the state”, NBER Working Paper \#10075.

Grenet, Julien (2013). "Is it enough to increase compulsory education to raise earnings? Evidence from French and British compulsory schooling laws", The Scandanavian Journal of Economics, 115(1): 176-210.

Grogger, Jeff (1997). "Incarceration-related costs of early childbearing”, In R. Maynard (ed.) Kids Having Kids: Economic costs and social consequences of teen pregnancy", Washington, DC, Urban Institute Press.

Grossman, Michael (1972). "On the concept of health capital and the demand for health", Journal of Political Economy, 80(2): 223-255.

Hofferth, Sandra (1987). "The social and economic consequences of teenage childbearing", In C. Hayes and S. Hofferth (Eds.) Risking the future: Adolescent sexuality, pregnancy, and childbearing, Washington, DC: National Academy Press.

Hoffman, Saul D., Foster, E. Michael and Frank F. Furstenberg (1993). "Reevaluating the costs of teenage childbearing", Demography, 30: 1-13.

Hotz, V. Joseph and Robert A. Miller (1988). "An empirical analysis of lifecycle fertility and female labor supply", Econometrica, 56(1): 91-118.

Katz, Michael S. (1976). "A history of compulsory education laws”, Fastback Series, No. 75, Bloomington, IN: Phi Delta Kappa.

Kenkel, Donald S. (1991). "Health behavior, health knowledge and schooling", Journal of Political Economy, 99(2): 287-305.

Klepinger, Daniel, Lundberg, Shelly and Robert Plotnick (1999). "How does adolescent fertility affect the human capital and wages of young women?" Journal of Human Resources, 34: 421448.

Lang, Kevin and David Kropp (1986). "Human capital versus sorting: The effects of compulsory attendance laws", Quarterly Journal of Economics, 101(3): 609-624.

Lleras-Muney, Adriana (2002). "Were compulsory education and child labor laws effective? Analysis from 1915 to 1939 in the U.S.", Journal of Law and Economics, 45(2): 401-435.

Lleras-Muney, Adriana (2005). "The relationship between education and adult mortality in the United States”, Review of Economic Studies, 72(1): 189-221.

Lochner, Lance and Enrico Moretti (2004). "The effect of education on crime: Evidence from prison inmates, arrests and self-reports", American Economic Review, 94(1): 155-189. 
Lovenheim, Michael F, Randall Reback and Leigh Wedenoja (2014). "How does access to health care affect teen fertility and dropout rates? Evidence from school-based health centers", Working paper.

McCrary, Justin and Heather Royer (2011). "The effect of female education on fertility and child health: Evidence from school entry policies using exact date of birth", American Economic Review, 101(1): 158-195.

Meghir, Costas and Martin Palme (2005). "Education reform, ability and parental background", American Economic Review, 95(1): 414-424.

Oreopoulos, Philip (2005). "Canadian compulsory schooling laws and their impact on educational attainment and future earnings”, Analytical Studies Branch Research Paper, No. 521, Statistics Canada.

Oreopoulos, Philip (2006). "Estimating average and local average treatment effects of education when compulsory schooling laws really matter", American Economic Review, 96(1): 152-175.

Oreopoulos, Philip and Kjell G. Salvanes (2011). "Priceless: The non-pecuniary benefits of schooling", Journal of Economic Perspectives, 25(1): 159-184.

Phillips, Charles E. (1957). The development of Education in Canada. Toronto, Ontario: W.J. Gage and Company.

Pischke, Jorn-Steffen and Till von Wachter (2008). "Zero returns to compulsory schooling in Germany: Evidence and interpretation, Review of Economics and Statistics, 90(3): 592-598.

Rosenzweig, Mark and T. Paul Schultz (1982). "Market opportunities, genetic endowment, and intrafamily resource distribution, American Economic Review, 72: 803-815.

Stephens Jr., Melvin and Dou-Yan Yang (2014). "Compulsory education and the benefits of schooling”, American Economic Review, 104: 1777-1792.

Tanfer, K. and M.C. Horn (1985). "Contraceptive use, pregnancy and fertility patterns among single American women in their 20s, Family Planning Perspectives, 17(1): 10-19.

Willis, Robert (1973). "A new approach to the economic theory of fertility behavior", Journal of Political Economy, 81: S14-S64.

Wolpin, Kenneth (1984). "An estimable dynamic stochastic model of fertility and child mortality", Journal of Political Economy, 92: 852-874. 
Figure 1: Schematic for Identifying Women Who Were Teenagers When They Gave Birth

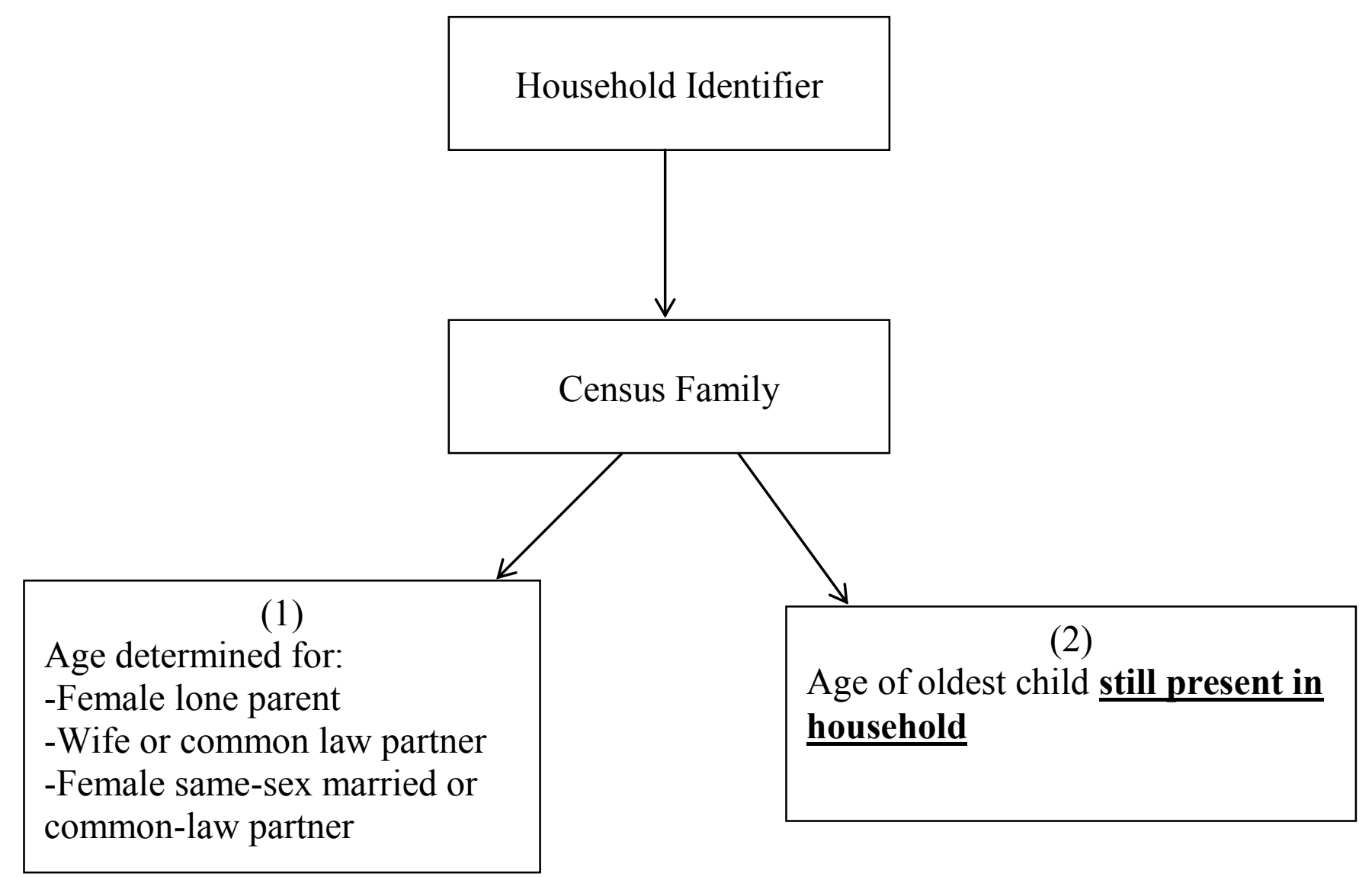

The differential between the age of the woman identified in box (1) and the child identified in box (2) determines the age at which the woman in box (1) gave birth to her eldest child. 


\section{Table 1: Sample Characteristics of Women who} Did or Did Not Give Birth as Teens

\begin{tabular}{|c|c|c|}
\hline & Gave Birth as a Teen & Did Not Give Birth as a Teen \\
\hline Age & $\begin{array}{l}28.80 \\
(3.93)\end{array}$ & $\begin{array}{l}28.44 \\
(3.97)\end{array}$ \\
\hline Education & $\begin{array}{l}10.89 \\
(2.39)\end{array}$ & $\begin{array}{l}13.01 \\
(2.91)\end{array}$ \\
\hline $\begin{array}{l}\text { Annual Income } \\
\text { (2002 dollars) }\end{array}$ & $\begin{array}{c}13736 \\
(12542)\end{array}$ & $\begin{array}{c}19524 \\
(17061)\end{array}$ \\
\hline Weeks Worked & $\begin{array}{c}24.38 \\
(22.16)\end{array}$ & $\begin{array}{c}32.65 \\
(21.60)\end{array}$ \\
\hline Married & $\begin{array}{c}0.785 \\
(0.390)\end{array}$ & $\begin{array}{c}0.640 \\
(0.472)\end{array}$ \\
\hline
\end{tabular}

The sample consists of women between the ages of 22 and 35 born in Canada, and is drawn from the 1976, 1981, 1986 and 1991 Canadian Censuses. 


\section{Table 2: Impact of Education on Being a Young Mother}

\begin{tabular}{|c|c|c|c|c|c|c|c|}
\hline & $\begin{array}{l}\text { Child } \\
\text { by } 16 \\
\end{array}$ & $\begin{array}{l}\text { Child } \\
\text { by } 17 \\
\end{array}$ & $\begin{array}{l}\text { Child } \\
\text { by } 18 \\
\end{array}$ & $\begin{array}{l}\text { Child } \\
\text { by } 19 \\
\end{array}$ & $\begin{array}{l}\text { Child } \\
\text { by } 20 \\
\end{array}$ & $\begin{array}{l}\text { Child } \\
\text { by } 21\end{array}$ & $\begin{array}{l}\text { Child } \\
\text { by } 22 \\
\end{array}$ \\
\hline $\begin{array}{c}\text { Mean of the } \\
\text { Dependent Variable }\end{array}$ & $\begin{array}{c}0.025 \\
(0.012)\end{array}$ & $\begin{array}{c}0.047 \\
(0.019)\end{array}$ & $\begin{array}{c}0.086 \\
(0.031)\end{array}$ & $\begin{array}{c}0.140 \\
(0.046)\end{array}$ & $\begin{array}{c}0.205 \\
(0.061)\end{array}$ & $\begin{array}{c}0.274 \\
(0.072)\end{array}$ & $\begin{array}{c}0.347 \\
(0.080)\end{array}$ \\
\hline OLS Estimates & $\begin{array}{l}-0.006 \\
{[0.048]}\end{array}$ & $\begin{array}{c}-0.006 \\
{[0.116]}\end{array}$ & $\begin{array}{l}-0.001 \\
{[0.863]}\end{array}$ & $\begin{array}{c}0.009 \\
{[0.138]}\end{array}$ & $\begin{array}{c}0.014 \\
{[0.120]}\end{array}$ & $\begin{array}{c}0.012 \\
{[0.214]}\end{array}$ & $\begin{array}{c}0.009 \\
{[0.410]}\end{array}$ \\
\hline IV Estimates & $\begin{array}{c}-0.008 \\
{[0.458]}\end{array}$ & $\begin{array}{c}-0.020 \\
{[0.010]}\end{array}$ & $\begin{array}{c}-0.031 \\
{[0.032]}\end{array}$ & $\begin{array}{c}-0.028 \\
{[0.234]}\end{array}$ & $\begin{array}{c}-0.019 \\
{[0.638]}\end{array}$ & $\begin{array}{c}-0.024 \\
{[0.612]}\end{array}$ & $\begin{array}{c}-0.051 \\
{[0.368]}\end{array}$ \\
\hline First Stage Coefficient & & & & $\begin{array}{c}0.264 \\
{[0.002]}\end{array}$ & & & \\
\hline
\end{tabular}

Coefficients are listed in each cell with p-values in brackets underneath. The sample consists of women between the ages of 22 and 35 born in Canada, and is drawn from the 1976, 1981, 1986 and 1991 Canadian Censuses. The dependent variable is the percentage of women within each year-of-birth/province-of-birth/Census-extract cell who have had a child by a certain age (which is listed in the column heading). There are a number of control variables in the model:(i) sets of indicator variables for year-of-birth, province of birth, and Census from which the data were drawn; (ii) variables based on cell-specific averages, such as: a quartic in age, the percentage of individuals in a rural setting, the percentage of individuals employed in manufacturing, percentage of individuals married, percentage of aboriginal respondents, percentage of immigrants; (iii) variables based on provincial-level data, including: real annual provincial school expenditures per capita, number of provincial schools per capita, number of provincial teachers per capita, real provincial per capita spending on social programs. Standard errors are clustered at the provincial level, and calculated using the Wild Cluster Bootstrap. 


\section{Table 3: Impact of the Instrument on Educational Attainment for Particular Grade Levels}

\begin{tabular}{|c|c|c|c|c|c|c|c|}
\hline & $\begin{array}{l}\text { At least } \\
\text { Grade } 7\end{array}$ & $\begin{array}{l}\text { At least } \\
\text { Grade } 8\end{array}$ & $\begin{array}{l}\text { At least } \\
\text { Grade } 9\end{array}$ & $\begin{array}{l}\text { At least } \\
\text { Grade } 10\end{array}$ & $\begin{array}{l}\text { At least } \\
\text { Grade } 11\end{array}$ & $\begin{array}{c}\text { At least } \\
\text { High } \\
\text { School }\end{array}$ & $\begin{array}{c}\text { At least } \\
\text { Some } \\
\text { College }\end{array}$ \\
\hline $\begin{array}{l}\text { Mean of the } \\
\text { Dependent } \\
\text { Variable }\end{array}$ & 0.981 & 0.970 & 0.946 & 0.909 & 0.835 & 0.743 & 0.505 \\
\hline $\begin{array}{l}\text { Coefficient } \\
\text { on Instrument }\end{array}$ & $\begin{array}{c}0.019 \\
{[<0.001]}\end{array}$ & $\begin{array}{c}0.070 \\
{[<0.001]}\end{array}$ & $\begin{array}{c}0.057 \\
{[<0.001]}\end{array}$ & $\begin{array}{c}0.072 \\
{[<0.001]}\end{array}$ & $\begin{array}{c}0.048 \\
{[0.006]}\end{array}$ & $\begin{array}{c}0.030 \\
{[0.070]}\end{array}$ & $\begin{array}{c}-0.017 \\
{[0.010]}\end{array}$ \\
\hline
\end{tabular}

Coefficients are listed in each cell with p-values in brackets underneath. The sample consists of women between the ages of 22 and 35 born in Canada, and is drawn from the 1976, 1981, 1986 and 1991 Canadian Censuses. The dependent variable is the percentage of women within each year-of-birth/province-of-birth/Census-extract cell who have had a child by a certain age (which is listed in the column heading). There are a number of control variables in the model:(i) sets of indicator variables for year-of-birth, province of birth, and Census from which the data were drawn; (ii) variables based on cell-specific averages, such as: a quartic in age, the percentage of individuals in a rural setting, the percentage of individuals employed in manufacturing, percentage of individuals married, percentage of aboriginal respondents, percentage of immigrants; (iii) variables based on provincial-level data, including: real annual provincial school expenditures per capita, number of provincial schools per capita, number of provincial teachers per capita, real provincial per capita spending on social programs. Standard errors are clustered at the provincial level, and calculated using the Wild Cluster Bootstrap. 
Table 4: Impact of Education on Total Number of Children Conceived by a Given Age

\begin{tabular}{|c|c|c|c|c|c|c|c|}
\hline & $\begin{array}{l}\text { Number of } \\
\text { Children } \\
\text { by } 16\end{array}$ & $\begin{array}{l}\text { Number of } \\
\text { Children } \\
\text { by } 17\end{array}$ & $\begin{array}{l}\text { Number of } \\
\text { Children } \\
\text { by } 18\end{array}$ & $\begin{array}{c}\text { Number of } \\
\text { Children } \\
\text { by } 19\end{array}$ & $\begin{array}{l}\text { Number of } \\
\text { Children } \\
\text { by } 20\end{array}$ & $\begin{array}{c}\text { Number of } \\
\text { Children } \\
\text { by } 21\end{array}$ & $\begin{array}{c}\text { Number of } \\
\text { Children } \\
\text { by } 22\end{array}$ \\
\hline $\begin{array}{l}\text { Mean of the } \\
\text { Dependent } \\
\text { Variable }\end{array}$ & $\begin{array}{c}0.024 \\
(0.007)\end{array}$ & $\begin{array}{c}0.051 \\
(0.017)\end{array}$ & $\begin{array}{c}0.107 \\
(0.035)\end{array}$ & $\begin{array}{c}0.197 \\
(0.059)\end{array}$ & $\begin{array}{c}0.318 \\
(0.086)\end{array}$ & $\begin{array}{c}0.466 \\
(0.113)\end{array}$ & $\begin{array}{c}0.631 \\
(0.140)\end{array}$ \\
\hline $\begin{array}{c}\text { OLS } \\
\text { Estimates }\end{array}$ & $\begin{array}{l}-0.009 \\
{[0.002]}\end{array}$ & $\begin{array}{l}-0.017 \\
{[0.002]}\end{array}$ & $\begin{array}{l}-0.025 \\
{[0.002]}\end{array}$ & $\begin{array}{l}-0.029 \\
{[0.002]}\end{array}$ & $\begin{array}{l}-0.037 \\
{[0.004]}\end{array}$ & $\begin{array}{l}-0.052 \\
{[0.002]}\end{array}$ & $\begin{array}{l}-0.071 \\
{[0.002]}\end{array}$ \\
\hline IV Estimates & $\begin{array}{c}-0.008 \\
{[0.458]}\end{array}$ & $\begin{array}{c}-0.020 \\
{[0.010]}\end{array}$ & $\begin{array}{c}-0.031 \\
{[0.032]}\end{array}$ & $\begin{array}{c}-0.028 \\
{[0.234]}\end{array}$ & $\begin{array}{c}-0.019 \\
{[0.638]}\end{array}$ & $\begin{array}{c}-0.024 \\
{[0.612]}\end{array}$ & $\begin{array}{c}-0.051 \\
{[0.368]}\end{array}$ \\
\hline
\end{tabular}

$\overline{\text { Coefficients are listed in each cell with p-values in brackets underneath. The sample consists of women between the ages of } 22}$ and 35 born in Canada, and is drawn from the 1976, 1981, 1986 and 1991 Canadian Censuses. The dependent variable is the percentage of women within each year-of-birth/province-of-birth/Census-extract cell who have had a child by a certain age (which is listed in the column heading). There are a number of control variables in the model:(i) sets of indicator variables for year-of-birth, province of birth, and Census from which the data were drawn; (ii) variables based on cell-specific averages, such as: a quartic in age, the percentage of individuals in a rural setting, the percentage of individuals employed in manufacturing, percentage of individuals married, percentage of aboriginal respondents, percentage of immigrants; (iii) variables based on provincial-level data, including: real annual provincial school expenditures per capita, number of provincial schools per capita, number of provincial teachers per capita, real provincial per capita spending on social programs. Standard errors are clustered at the provincial level, and calculated using the Wild Cluster Bootstrap. 
Appendix Table 1: Variation in the instrument

\begin{tabular}{|c|c|c|c|c|}
\hline & $\begin{array}{c}\text { Initial } \\
\text { Dropout } \\
\text { Age }\end{array}$ & $\begin{array}{c}\text { Dropout } \\
\text { Age }=14\end{array}$ & $\begin{array}{c}\text { Dropout } \\
\text { Age }=15\end{array}$ & $\begin{array}{c}\text { Dropout } \\
\text { Age }=16\end{array}$ \\
\hline Newfoundland & $\begin{array}{c}\text { None Until } \\
1941\end{array}$ & $1942-1951$ & $1952-1986$ & $1987-2000$ \\
\hline PEI & $\begin{array}{c}13 \text { Until } \\
1937\end{array}$ & ... & 1938-1979 & $1980-2000$ \\
\hline Nova Scotia & $\begin{array}{l}12 \text { Until } \\
1933\end{array}$ & $\cdots$ & $\cdots$ & $1933-2000$ \\
\hline $\begin{array}{c}\text { New } \\
\text { Brunswick }\end{array}$ & $\begin{array}{l}\text { None until } \\
1912\end{array}$ & $1913-1945$ & $\ldots$ & $\begin{array}{c}1946-1998 \\
\text { (18 thereafter) }\end{array}$ \\
\hline Quebec & $\begin{array}{c}\text { None Until } \\
1942\end{array}$ & $1943-1960$ & 1961-1987 & $1988-2000$ \\
\hline Ontario & & $1900-1953$ & & $1954-2000$ \\
\hline Manitoba & $\begin{array}{c}\text { None Until } \\
1906 \\
\text { Then } 12 \\
\text { until } 1913\end{array}$ & 1914-1962 & & $1963-2000$ \\
\hline Saskatchewan & $\begin{array}{c}\text { None Until } \\
1908\end{array}$ & $1909-1921$ & $1922-1963$ & $1964-2000$ \\
\hline Alberta & $\begin{array}{c}\text { None Until } \\
1909\end{array}$ & $1910-1922$ & $1922-1968$ & $1969-2000$ \\
\hline $\begin{array}{c}\text { British } \\
\text { Columbia }\end{array}$ & $\begin{array}{l}12 \text { Until } \\
1904\end{array}$ & $1905-1921$ & $1922-1988$ & $1989-2000$ \\
\hline
\end{tabular}




\section{Appendix Table 2: Impact of Education on Being a Young Mother}

\begin{tabular}{|c|c|c|c|c|c|c|c|}
\hline & $\begin{array}{l}\text { Child } \\
\text { by } 16 \\
\end{array}$ & $\begin{array}{l}\text { Child } \\
\text { by } 17\end{array}$ & $\begin{array}{l}\text { Child } \\
\text { by } 18\end{array}$ & $\begin{array}{l}\text { Child } \\
\text { by } 19\end{array}$ & $\begin{array}{l}\text { Child } \\
\text { by } 20\end{array}$ & $\begin{array}{l}\text { Child } \\
\text { by } 21\end{array}$ & $\begin{array}{l}\text { Child } \\
\text { by } 22\end{array}$ \\
\hline $\begin{array}{c}\text { Mean of the } \\
\text { Dependent Variable }\end{array}$ & $\begin{array}{c}0.025 \\
(0.012)\end{array}$ & $\begin{array}{c}0.047 \\
(0.019)\end{array}$ & $\begin{array}{c}0.086 \\
(0.031)\end{array}$ & $\begin{array}{c}0.140 \\
(0.046)\end{array}$ & $\begin{array}{c}0.205 \\
(0.061)\end{array}$ & $\begin{array}{c}0.274 \\
(0.072)\end{array}$ & $\begin{array}{c}0.347 \\
(0.080)\end{array}$ \\
\hline OLS Estimates & $\begin{array}{l}-0.003 \\
{[0.028]}\end{array}$ & $\begin{array}{l}-0.003 \\
{[0.278]}\end{array}$ & $\begin{array}{c}0.003 \\
{[0.400]}\end{array}$ & $\begin{array}{c}0.013 \\
{[0.002]}\end{array}$ & $\begin{array}{c}0.019 \\
{[<0.001]}\end{array}$ & $\begin{array}{c}0.019 \\
{[<0.001]}\end{array}$ & $\begin{array}{c}0.018 \\
{[0.004]}\end{array}$ \\
\hline IV Estimates & $\begin{array}{l}-0.008 \\
{[0.222]}\end{array}$ & $\begin{array}{l}-0.017 \\
{[0.008]}\end{array}$ & $\begin{array}{l}-0.020 \\
{[0.088]}\end{array}$ & $\begin{array}{l}-0.015 \\
{[0.516]}\end{array}$ & $\begin{array}{c}-0.004 \\
{[0.900]}\end{array}$ & $\begin{array}{l}-0.006 \\
{[0.886]}\end{array}$ & $\begin{array}{l}-0.014 \\
{[0.846]}\end{array}$ \\
\hline First Stage Coefficient & & & & $\begin{array}{c}0.495 \\
{[<0.001]}\end{array}$ & & & \\
\hline
\end{tabular}

Coefficients are listed in each cell with p-values in brackets underneath. The sample consists of women between the ages of 22 and 35 born in Canada, and is drawn from the 1976, 1981, 1986 and 1991 Canadian Censuses. The dependent variable is the percentage of women within each year-of-birth/province-of-birth/Census-extract cell who have had a child by a certain age (which is listed in the column heading). There are a number of control variables in the model:(i) sets of indicator variables for year-of-birth, province of birth, and Census from which the data were drawn; (ii) variables based on cell-specific averages, such as: a quartic in age, the percentage of individuals in a rural setting, the percentage of individuals employed in manufacturing, percentage of individuals married, percentage of aboriginal respondents, percentage of immigrants; (iii) Region-level trends, including: a linear trend for the four "maritime" provinces (Newfoundland, Prince Edward Island, Nova Scotia and New Brunswick), a linear trend for the two central provinces (Ontario and Quebec), and a linear for three of the four Western provinces (Saskatchewan, Alberta and British Columbia). Standard errors are clustered at the provincial level, and calculated using the Wild Cluster Bootstrap 


\section{Appendix Table 3: Impact of Education on Total Number of Children Conceived by a Given Age}

\begin{tabular}{|c|c|c|c|c|c|c|c|}
\hline & $\begin{array}{c}\text { Number of } \\
\text { Children } \\
\text { by } 16 \\
\end{array}$ & $\begin{array}{c}\text { Number of } \\
\text { Children } \\
\text { by } 17 \\
\end{array}$ & $\begin{array}{c}\text { Number of } \\
\text { Children } \\
\text { by } 18 \\
\end{array}$ & $\begin{array}{c}\text { Number of } \\
\text { Children } \\
\text { by } 19\end{array}$ & $\begin{array}{l}\text { Number of } \\
\text { Children } \\
\text { by } 20\end{array}$ & $\begin{array}{c}\text { Number of } \\
\text { Children } \\
\text { by } 21\end{array}$ & $\begin{array}{c}\text { Number of } \\
\text { Children } \\
\text { by } 22\end{array}$ \\
\hline $\begin{array}{l}\text { Mean of the } \\
\text { Dependent } \\
\text { Variable }\end{array}$ & $\begin{array}{c}0.024 \\
(0.007)\end{array}$ & $\begin{array}{c}0.051 \\
(0.017)\end{array}$ & $\begin{array}{c}0.107 \\
(0.035)\end{array}$ & $\begin{array}{c}0.197 \\
(0.059)\end{array}$ & $\begin{array}{c}0.318 \\
(0.086)\end{array}$ & $\begin{array}{c}0.466 \\
(0.113)\end{array}$ & $\begin{array}{c}0.631 \\
(0.140)\end{array}$ \\
\hline $\begin{array}{c}\text { OLS } \\
\text { Estimates }\end{array}$ & $\begin{array}{l}-0.008 \\
{[0.002]}\end{array}$ & $\begin{array}{l}-0.016 \\
{[0.002]}\end{array}$ & $\begin{array}{l}-0.028 \\
{[0.002]}\end{array}$ & $\begin{array}{l}-0.033 \\
{[0.002]}\end{array}$ & $\begin{array}{l}-0.046 \\
{[0.002]}\end{array}$ & $\begin{array}{l}-0.068 \\
{[0.002]}\end{array}$ & $\begin{array}{l}-0.089 \\
{[0.002]}\end{array}$ \\
\hline IV Estimates & $\begin{array}{c}-0.011 \\
{[0.010]}\end{array}$ & $\begin{array}{l}-0.017 \\
{[0.014]}\end{array}$ & $\begin{array}{l}-0.019 \\
{[0.366]}\end{array}$ & $\begin{array}{l}-0.011 \\
{[0.726]}\end{array}$ & $\begin{array}{c}-0.007 \\
{[0.894]}\end{array}$ & $\begin{array}{c}-0.023 \\
{[0.652]}\end{array}$ & $\begin{array}{c}-0.055 \\
{[0.040]}\end{array}$ \\
\hline
\end{tabular}

$\overline{\text { Coefficients are listed in each cell with p-values in brackets underneath. The sample consists of women between the ages of } 22}$ and 35 born in Canada, and is drawn from the 1976, 1981, 1986 and 1991 Canadian Censuses. The dependent variable is the percentage of women within each year-of-birth/province-of-birth/Census-extract cell who have had a child by a certain age (which is listed in the column heading). There are a number of control variables in the model:(i) sets of indicator variables for year-of-birth, province of birth, and Census from which the data were drawn; (ii) variables based on cell-specific averages, such as: a quartic in age, the percentage of individuals in a rural setting, the percentage of individuals employed in manufacturing, percentage of individuals married, percentage of aboriginal respondents, percentage of immigrants; (iii) Region-level trends, including: a linear trend for the four "maritime" provinces (Newfoundland, Prince Edward Island, Nova Scotia and New Brunswick), a linear trend for the two central provinces (Ontario and Quebec), and a linear for three of the four Western provinces (Saskatchewan, Alberta and British Columbia). Standard errors are clustered at the provincial level, and calculated using the Wild Cluster Bootstrap 